\title{
Understanding of Human Rights through Civic Education in the 21st Century
}

\author{
Eneng Martini*, Meiwatizal Trihastuti \\ Civic Education \\ STKIP Pasundan, Permana \\ Cimahi, Indonesia \\ *eneng.martini13@gmail.com
}

\begin{abstract}
The reality is that there are still many human rights abuses that we see both among adults and school-aged children, this has to do with the level of understanding of human rights itself, as for the purpose of this paper is to explore how human rights understanding is associated with Ongoing Citizenship Education is in the 21st century, because a condition will affect the development of children especially in school age. The method used in this paper is the study of several sources of books, journals and other references that support this writing. from the results of the study theories can be concluded that In an effort to instill understanding of Human Rights through Citizenship Education now should be able to improve quality learning in accordance with the needs (based on IT) and competence of educators good and professional, uphold the legislation and able to maintain unity state, fostering students to be aware of the rights and duties of good citizens, and the planting of characters in accordance with the value of Pancasila value.
\end{abstract}

\section{Keywords-human rights; citizenship education; 21st century}

\section{INTRODUCTION}

Regarding human rights awareness every human must exist, because the recognition of the same dignity and dignity as human beings. As long as humans have not yet acknowledged the equality of human dignity and human dignity, it cannot be upheld. If human rights cannot be enforced it will continue violation and repression of human rights, both by society, nation, and government of a State. And really in pity if you look at the current situation the practice of human rights implementation is still far from what we expect. This is often the type of human rights violations that occur in society, government and family. The news quickly spread either through the mass media and electronic media that is easily accessed on the internet. So it is very sad when we listen especially for children who watch it because it has a positive and negative impact. Concerning the emphasis of human rights in civic education identified by the participating educational.

\author{
Alif Adhitya Candra \\ Civic Education \\ Universitas Pendidikan Indonesia \\ Bandung, Indonesia \\ alifadhitya@student.upi.edu
}

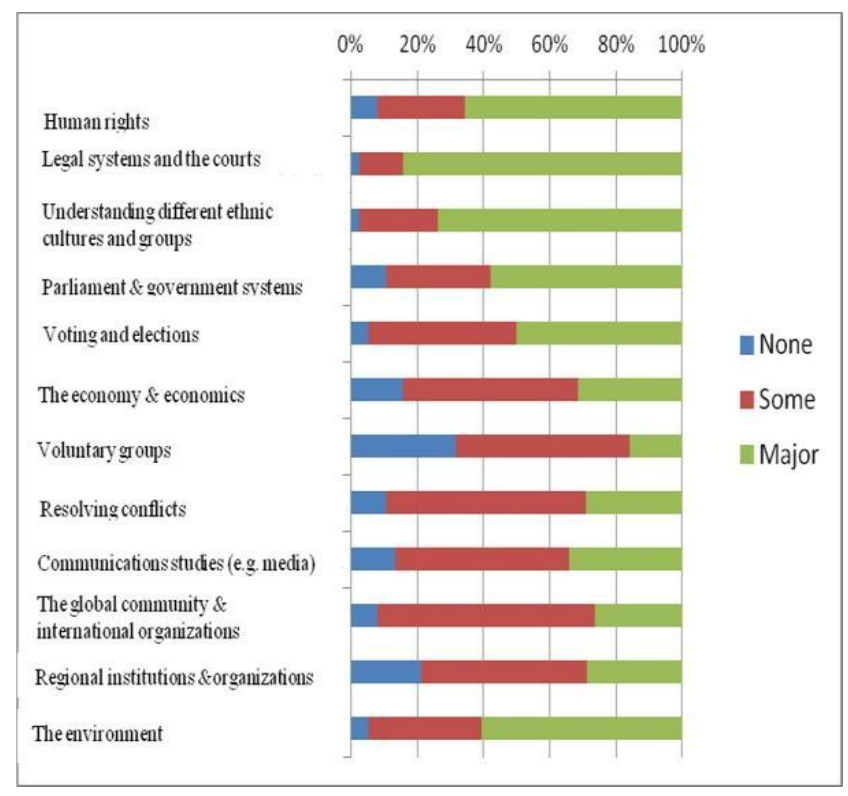

Fig. 1. Curriculum emphases for civic education identified by education systems participating in the international civic and citizenship study countries (Kennedy) [1].

Based on the above figure $80 \%$ of the countries identified as the main emphasis, "Legal and Judicial System". "Understanding Different Cultures and Ethnic Groups" is the main emphasis in more than $70 \%$ of countries. This was followed by "Human Rights" (65.8\%), "Environment" (60.5\%) and "Parliament and Governance System" (57.9\%).

In addition to the figure above, Kennedy reveals that the focus on human rights in the curriculum of civic education and citizenship in many countries is a reflection of the commitment to classical liberalism and individual freedom [1]. As for the frequent problems with human rights abuses, especially in children [2]

Their press release for this report summarizes some common problems facing children, such as: Refugees (children make up more than half the world's refugees), Exploitation of hazardous labor, Physical abuse, Sexual violence and exploitation, Recruitment as child soldiers, Abuse of police and arbitrary detention of street children, Orphans and abandoned children without adequate care, Sexual harassment and 
trafficking, Lack of access to education, or under-standard education.

Based on it is very important the world of education plays a role, especially in transferring knowledge about human rights to the students so that they can understand and implement it well in accordance with the ideals of the nation that is expected. Therefore, through Citizenship Education on the understanding of human rights in the 21 st century it is very important that this effort can be done through a good learning process in accordance with the objectives of learning in the curriculum and IT-based, fostering students to be aware of the rights and obligations as citizens who well, the inculcation of character education in life as well as providing insight into Globalization based on the value of Pancasila value.

\section{RESEARCH METHOD}

The approach in this study uses a literature study, which is to systematically elaborate from various concepts of Human Rights understanding derived from relevant journals, books and research in order to construct the understanding of Human Rights through Citizenship Education in the 21st century.

\section{RESULT AND DISCUSSION}

\section{A. Human Right}

Human Rights is a natural right which is owned by every human since birth [3]. Human Rights is a right inherent in human nature. While the Human Rights according to the Act. No. 39 of 1999 is a set of rights attached to the nature of human existence as a creature of God Almighty, and is a gift that must be respected, upheld, and protected by the State, law, government, and everyone for the honor and protection of human dignity and prestige.

With the existence of Human Rights we are made aware that all before God is the same as a divine being who has the right and with that right We cannot behave like we are because in our right therein there is the rights of others, as our God's creatures equally have self-esteem, and dignity. The fact that there are still people who are aware of Human Rights but in the implementation is still far expected, whether it is a violation of Human Rights a light and heavy. So here still need to give an understanding about Human Rights understanding to society and in education world.

Efforts to awaken the understanding of Human Rights have long been done, this can be seen from the early history of the rise of Human Rights, the first milestone of the triumphant awakening of human rights enforcement in the western view is to occur in England (15 June 1215), which is marked by the birth of the Magna Charta charter governing: 1) the power of the king should be limited; 2) human rights are more important than the power of the king; and 3) no independent citizen may be detained or deprived of his wealth, raped, exiled, or in any way resulting in his rights being deprived, except on the basis of legal interest. Human Rights was declared by the United Nations on December 10, 1948 at the Chailot Palace. In Indonesia Human Rights were first discussed by Bung Karno, Soepomo, Moh. Hatta and Moh. Yamin. According Soepomo and Soekarno, Human Rights derived from liberalist ideology that essentially is individualism so that human rights need not be included in the articles of the 1945 Constitution, whereas according to Moh. Hatta and Moh. Yamin points out the need to include articles on freedom of association, assembly and oral or written thoughts to ensure that the state does not fall into the concept of a unitary state.

In this case we can see also from the definition of human rights that the basic characteristics of human rights are:

- Human rights need not be given, bought or inherited. Human rights are part of the human being automatically.

- Human rights apply to all regardless of gender, origin, race, religion, ethnicity and political views.

- Human rights should not be violated. No one has the right to restrict or violate the rights of others. People still have human rights even though a State makes laws that do not protect and even violate human rights.

The claim that human rights are part of the modernity's progress narrative that human rights are a step forward in the advancement of human development and civilization maturity [4]. The next is that human rights are universal, challenging dehistorisisation, neutral, and inclusive claims. And last examine the liberal, articulated and petty subject in which human rights projects are based and the assumptions that relate them to 'Others'. With the above brief explanation can be a material to provide an understanding of Human Rights, especially through Citizenship education.

\section{B. Civic Education}

Education is not only the advance of knowledge alone but all aspects become the objective whether it is moral, religious, attitude, emotion and affection. So the school is expected not only to teach knowledge, but also to teach the value of human life as it deems necessary. The value of sociality, the value of democracy, the value of equality, brotherhood, etc. are all important to be developed, and this is contained in Citizenship Education.

Civic education is a basic subject designed to prepare young citizens to be able to play an active role in society, later as adults [5]. Meanwhile, according to Winataputra and Budimansyah disclose efforts to build civic competence, and help students / youth develop the ability to make clear and reasonable decisions for the public interest as citizens in diverse and global communities, the essence of civic education [6].

In this case civic education is a way of shaping citizens in understanding the rights and duties of good citizens and teaching citizens to take an active role in the life of society both nationally and internationally, participating responsibly and skillfully in conducting directional action and effective in their social life. So it can print smart and quality citizens because this life from year to year progresses and the challenges of life are getting heavier. The comprehensive intelligence referred to includes the following aspects [5]: 
- Spiritual intelligence, which is capable of selfactualizing through the heart to cultivate and strengthen the faith, piety and noble character including noble character and superior personality.

- Emotional intelligence, which is capable of selfactualization through taste to enhance the sensitivity and appreciation and beauty of art and culture, as well as the competence to express it

- Social intelligence, which is capable of selfactualization through social interaction.

- Intellectual intelligence, which is capable of selfactualization through thought to gain competence and independence in science and technology, and the actualization of critical, creative and imaginative intellectuals.

- Kinetic smart, which is capable of self- actualizing through sports to realize healthy, fit, resilient, spright, skilled, and trengginas man, and actualization of human beings.

The meaning of competent Indonesians is to have the following competence:

- Superior personality and proud of excellence

- High spirited fighting

- Independent

- Never give up

- Network builder and coach

- Make friends with change

- Productive

- Conscious quality

- Global oriented

- Lifelong learners

The above explanation gives an understanding that Indonesian citizens are not only smart and intelligent in the face of this life, but the need for a well-prepared and moral person is good to meet a better tomorrow than today.

\section{C. $21^{\text {st }}$ Century}

This 21 st century has experienced two decades which in this century of knowledge became the most important thing and known with the period of knowledge. In this era, all alternative efforts to meet the needs of life in various contexts are more knowledge-based. Efforts to meet the needs of knowledge-based education, knowledge-based economic development, development and empowerment of knowledgebased communities and development in the field of knowledgebased industries [7].

With knowledge-based and high technology then in the 21 st century, education is very important to ensure learners in having the skills to learn and innovate, skills use technology and information media, and can work, and survive by using skills to live. The 21 st century is also marked by the abundance of (1) information available anywhere and accessible at any time; (2) faster computing; (3) automation that replaces routine jobs; and (4) communication that can be done from anywhere and anywhere [8].

The style of learning activities in the knowledge period must be tailored to the knowledge needs of the knowledge age. The learning materials should provide a more authentic design to through the challenges in which learners can collaborate on creating solutions to problem-solving problems. Problem solving leads to questions and finds answers by learners who can then look for problem solving in the context of learning using available information resources [9]. With this kind of learning activities, learners will be brought to the real world that can combine theories and real lives, where at the moment many problems that arise that must immediately take the solution, especially related to Human Rights.

Learning 21st Century is a learning that integrates literacy skills, knowledge skills, skills and attitudes, and mastery of technology [10]. With the literacy is the main capital in the learning process so that here can give birth to humans who can think more creative and critical from the way of thinking LOTS towards HOTS and based on the value of Pancasila and the 1945 Constitution. And collaborate between science and real life so that the science can form teak a good self and have a good attitude or character to be a noble human being. The educational skills of the 21 st century are [10]

- Critical Thinking and Problem Solving Skill

- communication Skills

- Creativity and Innovation

- Collaboration

In addition to the skills that must be possessed by learners in this century as educators must have a skill in transferring knowledge so that it can be easily understood and can be implemented properly in life as to which the competence must have is:

- Planning learning, implementing quality learning process, and assess and evaluate learning outcomes.

- Enhance and develop academic and competency qualifications sustainably in line with the development of science, technology, and art.

- Be objective and non-discriminatory based on the consideration of gender, religion, tribe, and certain physical conditions, or family background, and socioeconomic status of learners in learning.

- Uphold the legislation, law, and code of ethics of teachers, as well as religious and ethical values.

- Maintain and cultivate the unity and unity of the nation.

\section{Understanding of Human Rights Through Civic Education} In The 21st Century

To find out how the understanding of Human Rights through Citizenship Education in the 21 st century which will 
ultimately give birth to good citizens and know about the rights and obligations this cannot be separated from what we should do such as: must improve the quality of learning in accordance with the needs of the times, competence good educators and professionals, uphold the legislation and able to maintain the unity of the nation, so as to nurture the students to be aware of the rights and obligations as good citizens, and have a character that matches the value of Pancasila value in life.

The Global Citizenship Commission both affirms the continued relevance and inspirational power of UDHR and seeks further recognition and respect for human rights for all citizens of the world, given its development in the 21 st century [11]. So it is important for us to respect the enforcement of human rights in life and all must go through the process and container in the implementation as expressed by Azis Wahab and Safriya that the field of study PPKn in accordance with the function and its purpose has been a means to foster citizens to better know the rights and a must in the life of nation and state. This explains that with Citizenship Education will provide an understanding of the rights and obligations of citizens, especially here about Human Rights which are the natural rights which are owned by every human being [12]. And education in Indonesia based on Pancasila and the 1945 Constitution, so by providing understanding of Human Rights through Citizenship Education will be realized the ideals of the nation that is to educate the life of noble break nation and has a broad national and global insights based on the values Pancasila. Then Brown discloses about human rights education having a very important role to play. Fostering a universal culture of human rights among all individuals and institutions through transformative human rights education from the bottom up can add an important boost to the adoption and enforcement of legal standards by top-down governments [11]. The Commission calls on governments, international organizations and LSM to encourage and support transformative human rights education.

\section{CONCLUSION}

The reality we face about human rights today is still far from what we expect, it is often encountered or seen either through the mass media and electronic media and easy to be accessed via the internet whether it is a violation of minor or serious rights. With the 21 st century is marked by a very high technology acceleration it can have a positive and negative impact for the nation's successors. Therefore, the role of education is needed for the sustainability of this nation's life should not be brought to the flow of globalization, then one way to apply this understanding of Human Rights is through Citizenship Education, with Citizenship Education is a subject that focuses on the formation of citizens who able to understand the rights and obligations to become intelligent and characteristic citizens in accordance with Pancasila and the 1945 Constitution. In an effort to instill the understanding of Human Rights through Citizenship Education, namely: to improve quality learning in accordance with the needs of the IT-based era and the competence of good educators and professionals, uphold the legislation and able to maintain the unity of the country, fostering students to be aware of the rights and obligations as a good citizen, and the planting of characters in accordance with the value of Pancasila value.

\section{REFERENCES}

[1] K.J. Kennedy, Global Trends In Civic and Citizenship Educations: What Are The Lesson For Nation States?, OPPEN ACCES, Education Science, 2012.

[2] A. Shah, Rights Of The Child, Global Issues Sicial, Political, Economic and Environmental Issues that Affect Us All, available at http://www.globalissues.org/article/152/rights-ofthe- child, 2013.

[3] I. Affandi and Suryadi, K, Hak Azasi Manusia, Jakarta: Universitas Terbuka, 2017.

[4] R. Kapur, Human Rights in The 21st Century: Taking a Walk on The Dark Side, Article in the Sidney law Review, available at https://www.researchgate.net/publication/259808567, 2016.

[5] D. Budimansyah, and Suryadi, K, PKN dan Masyarakat Multikultural, Program Studi Pendiidkan Kewarganegaraan Sekolah Pascasarjana, Universitas Pendidikan Indonesia, 2018.

[6] D. Budimansyah, and S. Winataputra, Civic Education Konteks, Landasan, Bahan Ajar dan Kultur Kelas, Program Studi Pendidikan Kewarganegaraan Pascasarjana. Universitas Pendidikan Indonesia, 2007.

[7] A. Mukadis, Sosok Manusia Indonesia Unggul dan berkarakter dalam Bidalang Teknologi sebagai Tuntutan Hidup di Era Globalisasi, 2013.

[8] Kemendikbud, Penyelenggara Pendiidkan Sistem Ganda pada Sekolah Menengah Kejuruan, Jakarta: Direktorat Pendidikan Menengah Kejuruan, 2013.

[9] B. Triling, and Hood. P, Learning, Technology, and Education Reform in The Knowledge age, 1999.

[10] Kemendikbud, Jakarta: Direktorat Pembinaan SMA. Direktorat Jendral Pendidikan Dasar dan Menengah, 2017.

[11] G. Brown, The Universal Declaration of Human Rights in the 21st Century: A living Document in a Changing Wrold, A report by the Global Citizenship Commisson, Global Institut For Advanced Study (NYU), 2016.

[12] A.A. Wahab and Safriya, Teori dan landasan Pendidikan Kewarganegaraan, Bandung: Alfabeta, 2011. 